\title{
PENGARUH MOTIVASI KERJA DAN KOMPENSASI TERHADAP KEPUASAN KERJA GURU SMK SWASTA DI WILAYAH TIMUR KABUPATEN PEMALANG
}

\author{
Arif Rahman Hakim1, Muhdi2 \\ ${ }^{1}$ Universitas Negeri Yogyakarta \\ 2Universitas PGRI Semarang \\ e-mail: arif_rahman@uny.ac.id
}

\begin{abstract}
The purpose of this study is to (1) To find out the importance of work motivation on vocational teacher job satisfaction in the supervision of the eastern part of Pemalang Regency, (2) to find out the effect of compensation on job satisfaction of private Vocational Teachers in the supervisory area of the eastern part of Pemalang Regency, (3) to determine the effect of work motivation and compensation on job satisfaction of private vocational school teachers in the supervisory region of the eastern part of Pemalang Regency. Data collection method used was a questionnaire method. Analysis of the data used is descriptive analysis, test requirements and hypothesis testing which includes simple linear regression analysis and multiple regression analysis. Factors that affect teacher job satisfaction include work motivation and compensation $54.4 \%$, the remaining $45.6 \%$ is influenced by variables outside the study. Work motivation and compensation of teachers in private vocational supervisory regions in the eastern part of Pemalang Regency are categorized while the job satisfaction of teachers in private vocational supervisory areas in the eastern part of Pemalang district is categorized high.
\end{abstract}

Keywords: work motivation, compensation, satisfaction, education management

\section{PENDAHULUAN}

Salah satu permasalahan yang paling mendasar dan sedang dihadapi oleh bangsa Indonesia adalah rendahnya mutu pendidikan pada setiap jenjang dan satuan pendidikan dasar dan menengah. Berbagai usaha telah dilakukan untuk meningkatkan mutu pendidikan nasional antara lain melalui berbagai pelatihan dan peningkatan kualifikasi guru, pengadaan buku, perbaikan sarana prasarana pendidikan lainnya, serta peningkatan mutu manajemen sekolah. Namun, dari berbagai indikator mutu pendidikan belum menunjukkan peningkatan yang merata, sebagian sekolah terutama di kota-kota menunjukkan peningkatan mutu pendidikan yang cukup menggembirakan namun sebagian lainnya masih memprihatikan.

Ardana (2012: 147) menyatakan kepuasan kerja merupakan cara pandang seseorang, baik yang bersifat positif maupun negatif tentang pekerjaannya. Menurut Robbins (2008: 107) mendefinisikan kepuasan kerja sebagai suatu perasaan positif atau negatif tentang pekerjaan seseorang yang merupakan hasil dari sebuah evaluasi karakteristiknya. Dalam meningkatkan kepuasan kerja, organisasi dalam hal ini sekolah menempuh beberapa cara misalnya melalui pendidikan, pelatihan, menciptakan lingkungan kerja yang kondusif, pemberian motivasi pemberian dan kompensasi yang layak. Melalui proses-proses tersebut, 
guru diharapkan akan lebih memaksimalkan tanggung jawab atas pekerjaan mereka karena para guru telah terbekali oleh pendidikan dan pelatihan yang tentu berkaitan dengan implementasi kerja mereka. Pemberian motivasi dan pemberian kompensasi pada dasarnya adalah hak para guru dan merupakan kewajiban dari pihak perusahaan untuk mendukung kontribusi kepuasan kerja guru dalam rangka mencapai tujuan yang telah ditentukan.

Hasibuan (2014: 95) berpendapat salah satu faktor munculnya kepuasan kerja adalah adanya motivasi kerja guru. Motivasi adalah pemberian daya penggerak yang menciptakan kegairahan kerja seseorang, agar mereka mau bekerja sama, bekerja efektif dan terintegrasi dengan segala upaya untuk mencapai kepuasan.

Masalah kebijakan dan administrasi yang belum mengatur lekat pada program sekolah untuk menjamin guru mempunyai rasa aman, hubungan antar pribadi menjadi penting dikarenakan kebutuhan guru akan jumlah jam ditiap semester sangat berpengaruh untuk income yang didapat, pengakuan atau penghargaan yang hanya wacana atau pelengkap administrasi akreditasi tanpa ada realisasi, dan tanggung jawab yang diberikan terlalu berlebih tidak sesuai dengan jobdesk seorang guru.

Berdasarkan penjabaran di atas kepuasan kerja merupakan wujud dari kesenangan yang dirasakan oleh seseorang atas peranan atau pekerjaannya dan juga merupakan hasil dari bentuk interaksi antara individu dan lingkungan pekerjaannya, ketika seseorang mendapatkan kesenangan dalam pekerjaannya, maka ia akan berusaha semaksimal mungkin dengan segala kemampuan yang dimikinya untuk menyelesaikan tugas-tugasnya. Adapun indikator kepuasan kerja kepuasan meliputi: kesempatan berkembang, kepercayaan, gaji (upah) yang diperoleh, supervisi, dan jaminan kerja

Di wilayah kepengawasan timur Kab. Pemalang adalah sekolah yang belum dibekali motivasi yang cukup dari pemimpinnya guru-gurunya mempunyai kepuasan yang baik dan terus mengembangkan karir. Adapula Hasibuan (2010: 118) menyatakan bahwa "kompensasi dibedakan menjadi dua yaitu kompensasi langsung berupa gaji, upah, dan upah insentif, kompensasi tidak langsung atau kesejahteraan karyawan. Sementara Menurut Ardana (2012: 193) motivasi kerja adalah sesuatu yang menimbulkan dorongan atau semangat kerja atau pendorong semangat kerja.

Disimpulkan bahwa motivasi kerja adalah suatu proses yang dilakukan untuk menggerakkan guru agar perilaku mereka dapat diarahkan pada upaya mencapai tujuan yang ditetapkan oleh sekolah. Ada beberapa guru di SMK swasta di wilayah bagian timur Kab. Pemalang yang berotasi dari tahun 2015/2016 dan dapat digambarkan dari data tersebut bahwa jumlah guru di semester berikutnya berkurang dan memilih pekerjaan lain. Hal tersebut muncul sama persis seperti yang telah dijelaskan Robbins (2008: 117) bahwa kepuasan juga berpengaruh dengan perputaran karyawan, tetapi korelasi tersebut lebih kuat daripada yang diketahui tentang ketidakhadiran. Masalah yang lain muncul pada sekolah swasta di Kabupaten Pemalang adalah pembiayaannya sangat tergantung pada jumlah peserta didiknya. Sekolah dikatakan maju apabila muridnya banyak dan sudah barang tentu kesejahteraan guru karyawan di tempat tersebut tinggi pula. Sementara itu, ada juga beberapa sekolah yang muridnya sedikit juga tergolong 
maju dikarenakan pemberian motivasi yang baik pula dan langsung berpengaruh pada kepuasan kerja gurunya.

Masalah yang selanjutnya terkait dengan kompensasi yang diberikan. Guru mengharapkan kenaikan gaji, gaji yang diberikan sekarang dinilai kurang sesuai dengan kebutuhan yang semakin meningkat. Guru berharap kenaikan gaji diberikan berkala dalam periode tertentu. Yang terjadi selama ini kenaikan gaji sangat jarang diberikan. Bahkan terjadi beberapa perpindahan guru dari sekolah satu ke sekolah lain atau ke perusahaan lain. Kompensasi seringkali juga disebut penghargaan dan dapat didefinisikan sebagai setiap bentuk penghargaan yang diberikan kepada karyawan sebagai balas jasa atas kontribusi yang mereka berikan kepada organisasi. Definisi lain dari Hasibuan (2012: 118) tentang kompensasi adalah semua pendapatan yang berbentuk uang, barang langsung maupun tidak langsung yang diterima sebagai imbalan atas jasa yang diberikan.

Menurut Sutrisno (2012: 183) kompensasi dapat diberikan dalam berbagai macam bentuk, seperti: pemberian uang (gaji, tunjangan dan insentif), pemberian material dan fasilitas, dan kesempatan berkarir. Gaji dan upah adalah kompensasi yang diberikan kepada seseorang karyawan secara periodik. Tunjangan dan jasa adalah kompensasi yang diberikan karena karyawan dianggap telah ikut berpartisipasi dengan baik untuk mencapai tujuan perusahaan. Contoh: tunjangan jabatan, tunjangan keluarga, tunjangan transport, tunjangan perumahan, dan sebagainya. Insentif adalah kompensasi yang diberikan kepada karyawan karena keberhasilan prestasi atas prestasinya. Kompensasi pelengkap (fringe benefits) merupakan kompensasi yang diberikan yang tidak terkait langsung dengan hasil kerja karyawan yang bersangkutan. Kompensasi pelengkap ini biasa disebut sebagai kompensasi tak langsung. Contoh: kompensasi kesehatan, kompensasi transportasi, tunjangan hari tua, kompensasi beras dan lain sebagainya.

Dari pemaparan di atas diartikan bahwa kompensasi merupakan segala sesuatu yang diterima guru sebagai balas jasa atas apa yang telah dikerjakan. Indikator kompensasi antara lain gaji dan upah, tunjangan dan jasa, insentif dan kompensasi pelengkap (fringe benefits).

\section{METODE PENELITIAN}

Pendekatan yang digunakan adalah pendekatan kuantitatif. Pendekatan kuantitatif digunakan kerena merujuk dari penelitian sebelumnya yang relevan sudah menunjukan bahwa akan merujuk pada diterimanya hipotesis penelitian. Dalam penelitian ini yang menjadi populasi adalah guru SMK wilayah kepengawasan bagian timur di Kabupaten Pemalang yang berjumlah 486. Sehingga sampel dalam penelitian ini berjumlah 83 orang dan proses sampling yang digunakan adalah proportional random sampling. Teknik pengumpulan data dengan kuesioner.

Sementara itu dalam penelitian ini juga memaparkan definisi operasional variabel yang memberi uraian tentang masing-masing variabel yang berisi kesimpulan indikator dan cara pengukurannya. Berikut definisi operasional tiap variabelnya: Kepuasan kerja guru merupakan wujud dari kesenangan yang dirasakan oleh seseorang atas peranan atau pekerjaannya dan juga merupakan hasil dari bentuk interaksi antara individu dan lingkungan pekerjaannya, ketika seseorang mendapatkan kesenangan dalam pekerjaannya. Untuk mengukur 
kepuasan kerja kepuasan meliputi: kesempatan berkembang, kepercayaan, gaji (upah) yang diperoleh, supervisi, dan jaminan kerja. Alat ukur yang digunakan penelitian untuk variabel kepuasan kerja yaitu kuisioner tentang kepuasan kerja dengan responden guru.

Motivasi kerja adalah suatu proses yang dilakukan untuk menggerakkan guru agar perilaku mereka dapat diarahkan pada upaya mencapai tujuan yang ditetapkan oleh sekolah. Adapun kemudian indikator dari motivasi kerja dapat disimpulkan dengan kebijaksanaan dan administrasi, hubungan antar pribadi, pengakuan/ penghargaan, pengembangan dan tanggung jawab. Alat ukur yang digunakan penelitian untuk variabel motivasi kerja yaitu kuesioner tentang motivasi kerja dengan responden guru.

Kompensasi merupakan segala sesuatu yang diterima guru sebagai balas jasa atas apa yang telah dikerjakan. Dan kemudian indikator dari kompensasi adalah gaji dan upah, tunjangan dan jasa, insentif dan kompensasi pelengkap (fringe benefits). Alat ukur yang digunakan penelitian untuk variabel kompensasi yaitu kuisioner tentang kompensasi dengan responden guru.

Hipotesis Pertama yang diajukan adalah motivasi kerja berpengaruh positif terhadap peningkatan kepuasan kerja guru. Hipotesis Kedua yang diajukan adalah kompensasi berpengaruh positif terhadap peningkatan kepuasan kerja guru. Hipotesis ketiga yang diajukan adalah motivasi kerja dan kompensasi berpengaruh positif terhadap peningkatan kepuasan kerja guru.

Angket yang akan digunakan dalam penelitian, perlu diujicobakan lebih dahulu dengan uji validitas dan uji reliabilitas. Sebelum melakukan pengujian hipotesis, terlebih dahulu akan dilakukan pengujian terjadinya penyimpangan terhadap asumsi klasik. Dalam asumsi klasik terdapat beberapa pengujian yang dilakukan, yakni uji Normalitas, uji Linieritas, uji Heterosdastisitas, uji autokorelasi, dan. uji Multikolonieritas. Selanjutnya, teknik analisis data dilakukan dengan analisis regresi linear sederhana, analisis regresi linear berganda, uji F, uji parsial (Uji-t), koefisien determinasi dan sumbangan relatif dan sumbangan efektif $\mathrm{X} 1, \mathrm{X} 2$, terhadap Y.

\section{HASIL PENELITIAN DAN PEMBAHASAN Hasil Penelitian}

Hipotesis Pertama yang diajukan adalah motivasi kerja berpengaruh positif terhadap peningkatan kepuasan kerja guru. Hipotesis Kedua yang diajukan adalah kompensasi berpengaruh positif terhadap peningkatan kepuasan kerja guru. Berdasarkan hasil pengujian analisis regresi yang telah dilakukan maka didapat hasil yang tersaji pada tabel di bawah ini:

1. Hasil Analisis Regresi Motivasi Kerja (X1) terhadap Kepuasan Kerja (Y)

Hasil analisis statistik regresi pengaruh Motivasi Kerja $\left(\mathrm{X}_{1}\right)$ terhadap Kepuasan Kerja (Y) dapat dilihat pada tabel berikut ini. 
Tabel 1.

Koefisien Regresi Motivasi Kerja (X1) terhadap Kepuasan Kerja (Y)

Coefficients(a)

\begin{tabular}{|c|c|c|c|c|c|c|}
\hline & & $\begin{array}{l}\text { Unstandardized } \\
\text { Coefficients }\end{array}$ & & $\begin{array}{l}\text { Standardized } \\
\text { Coefficients }\end{array}$ & & \\
\hline Model & & 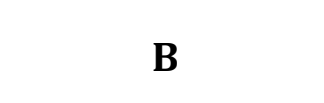 & $\begin{array}{l}\text { Std. } \\
\text { Error }\end{array}$ & Beta & $\mathbf{t}$ & Sig. \\
\hline \multirow[t]{2}{*}{1} & (Constant) & 18.989 & 13.724 & & 1.384 & .170 \\
\hline & $\begin{array}{l}\text { MOTIVASI_ } \\
\text { KERJA }\end{array}$ & .715 & .143 & .485 & 4.990 & .000 \\
\hline
\end{tabular}

a. Dependent Variable:

KEPUASAN_KERJA

Dari hasil analisis statistik regresi maka persamaan regresi pengaruhMotivasi Kerja ( $\mathrm{X}_{1}$ ) terhadap Kepuasan Kerja (Y) adalah $\mathrm{Y}=18.989+0,715 \mathrm{X}_{1}$. Persamaan tersebut dapat diartikan:

$\mathrm{a}=$ 18.989adalah nilai konstanta yang artinya jika motivasi kerja $\left(\mathrm{X}_{1}\right)$ dianggap konstan atau nol maka variabel kepuasan kerja guru (Y) mempunyai nilai sebesar 18.989

$\mathrm{b}=0,715$ menunjukan koefisien regresi positif, artinya apabila variabel motivasi kerja $\left(\mathrm{X}_{1}\right)$ meningkat maka kepuasan guru juga meningkat.

Berdasarkan hasil analisis statistik tersebut maka diperoleh nilai thitung sebesar 4.990 sedangkan nilai tabel dengan taraf kepercayaan 0,05, menunjukan angka sebesar 1.990 (4.990>1.994). Jadi thitung lebih besar dari ttabel yang berarti motivasi kerja $\left(\mathrm{X}_{1}\right)$ berpengaruh secara signifikan terhadap kepuasan kerja guru SMK Swasta di wilayah kepengawasan bagian timur kab. Pemalang.

Tabel 2.

Hasil Uji Anova Motivasi Kerja (X) terhadap Kepuasan Kerja (Y)

ANOVA $^{\mathrm{a}}$

\begin{tabular}{clccccc}
\hline Model & & $\begin{array}{c}\text { Sum of } \\
\text { Squares }\end{array}$ & df & $\begin{array}{c}\text { Mean } \\
\text { Square }\end{array}$ & F & Sig. \\
\hline \multirow{2}{*}{1} & Regression & 1.408 .595 & 1 & 1.408 .595 & 24.899 & $.000 \mathrm{a}$ \\
& Residual & 4.582 .273 & 81 & 56.571 & & \\
& Total & 5.990 .867 & 82 & & & \\
\hline
\end{tabular}

a. Predictors: (Constant), MOTIVASI_KERJA

b. Dependent Variable: KEPUASAN_KERJA

Berdasar hasil uji Anova diperoleh nilai F sebesar 24.899 dan kemudian akan dibandingkan dengan $F_{\text {tabel. }}$ Untuk melihat $F_{\text {tabel }}$ dalam pengujian hipotesis pada model regresi, perlu menentukan derajat bebas atau degree of freedom (df) atau dikenal dengan df2 dan juga dalam $\mathrm{F}$ tabel disimbolkan dengan $\mathrm{N} 2$. 
Hal ini ditentukan dengan rumus:

$\begin{array}{rlrl}\mathrm{df} 1= & \mathrm{k}-1 & \mathrm{df} 2 & =\mathrm{n}-\mathrm{k} \\ & =3-1 & & =83-3 \\ & =2 & & =80\end{array}$

Dimana $\mathrm{n}=$ Banyaknya observasi dalam kurun waktu data

Dimana $\mathrm{k}$ = Banyaknya variabel (bebas dan terikat)

Dalam pengujian ini dilakukan dengan tingkat kepercayaan $5 \%$ atau 0,05 , dalam hal ini bisa kita uji dengan rumus tersebut. Pada df1 $=3-1=2$ dan pada df $2=83-$ $3=80$, maka nilai $\mathrm{F}$ tabel adalah 3.11 .

Dari data tersebut maka $F_{\text {hitung }}>F_{\text {tabel }}(24.899<3.11)$ dengan nilai probabilitas (Sig) sebesar 0,000 lebih kecil dari 0,05 disimpulkan bahwa H1 diterima, yang berarti bahwa motivasi kerja $\left(\mathrm{X}_{1}\right)$ berpengaruh secara signifikan terhadap kepuasan kerja guru (Y) SMK Swasta di wilayah kepengawasan bagian timur kab. Pemalang.

Hasil pengujian model summary diketahui bahwa nilai koefisien korelasi adalah 0,485. Nilai ini dapat dinterpretasikan bahwa tingkat hubungan kedua variabel penelitian berada pada kategori tinggi. Hal ini berarti bahwa motivasi kerja $\left(\mathrm{X}_{1}\right)$ berpengaruh sebesar $48,5 \%$ terhadap kepuasan kerja guru (Y).

Berdasarkan hasil pengujian regresi yang telah diuraikan di atas dapat disimpulkan bahwa hipotesis yang menyatakan adanya pengaruh motivasi kerja terhadap kepuasan kerja guru SMK Swasta di wilayah kepengawasan bagian timur kab. Pemalang, terbukti.

2. Hasil Analisis Regresi Kompensasi (X2) terhadap Kepuasan Kerja (Y)

Hasil analisis statistik regresi pengaruh Kompesasi $\left(\mathrm{X}_{2}\right)$ terhadap Kepuasan Kerja (Y) dapat dilihat pada tabel berikut ini.

Tabel 3.

Koefisien Regresi Kompesasi ( $\mathrm{X}_{2}$ ) terhadap Kepuasan Kerja (Y)

\section{Coefficients ${ }^{a}$}

\begin{tabular}{llccccc}
\hline Model & & \multicolumn{2}{c}{$\begin{array}{c}\text { Unstandardized } \\
\text { Coefficients }\end{array}$} & $\begin{array}{c}\text { Standardized } \\
\text { Coefficients }\end{array}$ & T & Sig. \\
\cline { 3 - 6 } & & B & Std. Error & Beta & & \\
\cline { 2 - 6 } 1 & (Constant) & 46.377 & 8.265 & & 5.612 & .000 \\
& KOMPENSASI & .544 & .109 & .484 & 4.983 & .000 \\
\hline
\end{tabular}

a. Dependent Variable: KEPUASAN_KERJA

Dari hasil analisis statistik regresi maka persamaan regresi pengaruh Kompensasi $\left(\mathrm{X}_{2}\right)$ terhadap Kepuasan Kerja $(\mathrm{Y})$ adalah $\mathrm{Y}=46.377+0,544 \mathrm{X}_{2}$. Persamaan tersebut dapat diartikan:

$\mathrm{a}=46.377$ adalah nilai konstanta yang artinya jika kompensasi $\left(\mathrm{X}_{2}\right)$ dianggap konstan atau nol maka variabel kepuasan kerja guru $(\mathrm{Y})$ mempunyai nilai sebesar 46.377 
$\mathrm{b}=0,544$ menunjukan koefisien regresi positif, artinya apabila variabel kompensasi $\left(\mathrm{X}_{2}\right)$ meningkat maka kepuasan kerja guru juga meningkat.

Berdasarkan hasil analisis statistik tersebut maka diperoleh nilai thitung sebesar 4,983 sedangkan nilai tabel dengan taraf kepercayaan 0,05, menunjukan angka sebesar $1.994(4,983<1.994)$. Jadi thitung lebih besar dari tabel yang berarti kompensasi (X2) berpengaruh secara signifikan terhadap kepuasan kerja guru SMK Swasta di wilayah kepengawasan bagian timur kab. Pemalang.

Tabel 4.

Hasil Uji Anova Kompensasi (X2) terhadap Kepuasan Kerja (Y)

ANOVA $^{\mathrm{a}}$

\begin{tabular}{llccccc}
\hline Model & & $\begin{array}{c}\text { Sum of } \\
\text { Squares }\end{array}$ & Df & $\begin{array}{c}\text { Mean } \\
\text { Square }\end{array}$ & F & Sig. \\
\hline \multirow{2}{*}{1} & Regression & 1.405 .409 & 1 & 1.405 .409 & 24.826 & $.000 \mathrm{a}$ \\
& Residual & 4.585 .459 & 81 & 56.611 & & \\
& Total & 5.990 .867 & 82 & & & \\
\hline
\end{tabular}

a. Dependent Variable: KEPUASAN_KERJA

b. Predictors: (Constant), KOMPENSASI

Berdasar hasil uji Anova diperoleh nilai F sebesar 24,826 dan kemudian akan dibandingkan dengan $\mathrm{F}_{\text {tabel. }}$. Untuk melihat $\mathrm{F}$ tabel dalam pengujian hipotesis pada model regresi, perlu menentukan derajat bebas atau degree of freedom (df) atau dikenal dengan df2 dan juga dalam $\mathrm{F}$ tabel disimbolkan dengan N2.

Dari data tersebut maka $F_{\text {hitung }}>F_{\text {tabel }}(24,826>3.11)$ dengan nilai probabilitas (Sig) sebesar 0,000 lebih kecil dari 0,05 disimpulkan bahwa H2 diterima, yang berarti bahwa kompensasi (X2) berpengaruh secara signifikan terhadap kepuasan kerja guru (Y) SMK Swasta di wilayah kepengawasan bagian timur kab. Pemalang.

Berdasarkan hasil pengujian regresi yang telah diuraikan di atas dapat disimpulkan bahwa hipotesis yang menyatakan adanya pengaruh kompensasi terhadap kepuasan kerja guru SMK Swasta di wilayah kepengawasan bagian timur kab. Pemalang, terbukti.

\section{Pembahasan}

1. Motivasi Kerja terhadap Kepuasan Kerja Guru.

Berdasarkan hasil penelitian 83 responden yang telah menjawab kuisioner dapat dijelaskan bahwa motivasi kerja berpengaruh secara signifikan terhadap kepuasan kerja guru SMK Swasta di wilayah kepengawasan bagian timur Kabupaten Pemalang yang dikategorikan sangat tinggi sebanyak 15 orang (18\%), berkategorikan tinggi sebanyak 22 orang (27\%), berkategorikan sedang sebanyak 28 orang (34\%), berkategorikan rendah sebanyak 16 orang (19\%), dan berkategorikan sangat rendah sebanyak 2 orang (2\%), jumlah skor 6.257 dan ratarata 75,385 berada di kategori sedang maka dapat disimpulkan bahwa rata-rata motivasi kerja guru SMK Swasta di wilayah kepengawasan bagian timur Kabupaten Pemalang termasuk dikategorikan sedang.

Terdapat beberapa indikator variabel motivasi kerja yang termasuk kategori sangat tinggi yang perlu dipertahankan dan ditingkatkan yaitu indikator tanggung 
jawab. Sedangkan indikator lainnya rata-rata berada dalam kategori sedang sampai sangat rendah sehingga perlu ditingkatkan dan diperbaiki diantaranya adalah pengembangan, pengakuan/ penghargaan, hubungan antar pribadi, serta kebijakan dan administrasi.

Berdasarkan hasil analisis statistik tersebut maka diperoleh nilai thitung sebesar 4.990 sedangkan nilai ttabel dengan taraf kepercayaan 0,05, menunjukan angka sebesar 1.990 (4.990>1.994) yang berarti motivasi kerja (X1) berpengaruh secara signifikan terhadap kepuasan kerja guru SMK Swasta di wilayah kepengawasan bagian timur kab. Pemalang.

Diketahui bahwa nilai koefisien korelasi adalah 0,485. Nilai ini dapat dinterpretasikan bahwa tingkat hubungan kedua variabel penelitian berada pada kategori tinggi. Hal ini berarti bahwa motivasi kerja (X1) berpengaruh sebesar 48,5\% terhadap kepuasan kerja guru (Y). Berdasarkan hasil pengujian regresi yang telah diuraikan di atas dapat disimpulkan bahwa hipotesis yang menyatakan adanya pengaruh motivasi kerja terhadap kepuasan kerja guru SMK Swasta di wilayah kepengawasan bagian timur kab. Pemalang, terbukti. Penelitian lain yang konsisten dengan penelitian ini dilakukan oleh Mardiono (2014) yang berjudul "Pengaruh Motivasi Dan Disiplin Kerja Terhadap Kepuasan Kerja Karyawan" dari hasil penelitian tersebut menunjukan hasil motivasi dan disiplin kerja secara simultan berpengaruh signifikan terhadap kepuasan kerja karyawan.

Hasil analisis di atas menunjukan bahwa motivasi kerja mempunyai peranan penting untuk mendukung kepuasan kerja guru. Motivasi kerja sangat penting dan dibutuhkan oleh setiap guru untuk meningkatkan kepuasan kerja guru yang kemudian berimbas pada kinerja yang baik dan kualitas output siswa yang memiliki peningkatan kompetensi. Guru yang memiliki motivasi kerja tinggi akan melakukan pekerjaan dengan lebih semangat serta menggunakan kemampuan dan keterampilan serta pengetahuan yang dimilikinya yang tampak dalam tanggungjawab melaksanakan pekerjaan.

Setiap guru harus memiliki motivasi kerja yang tinggi sehingga dapat meningkatkan kepuasan kerja dan produktifitas yang baik bagi sekolah, apabila setiap guru memiliki motivasi kerja yang tinggi tentunya juga akan berimbas pada loyalitas terhadap sekolah, disiplin kerja, dan produktivitasnya hal ini juga tentunya akan sangat berimbas pada kepuasan kerja guru. Apabila guru memiliki keinginan yang kuat untuk terus berprestasi, memiliki hubungan yang harmonis dengan guru yang lain dan memiliki keinginan yang kuat untuk mendapatkan promosi jabatan dari atasan maka motivasi kerja yang dimiliki.

2. Kompensasi terhadap Kepuasan Kerja Guru

Berdasarkan hasil penelitian 83 responden yang telah menjawab kuisioner dapat dijelaskan bahwa kompensasi berpengaruh secara signifikan terhadap kepuasan kerja guru SMK Swasta di wilayah kepengawasan bagian timur Kabupaten Pemalang yang dikategorikan sangat tinggi sebanyak 10 orang (12\%), berkategorikan tinggi sebanyak 23 orang (28\%), berkategorikan sedang sebanyak 29 orang (35\%), berkategorikan rendah sebanyak 15 orang (18\%), dan berkategorikan sangat rendah sebanyak 6 orang (7\%), jumlah skor 6.257 dan ratarata 75,385 berada di kategori sedang. Berdasarkan data tersebut dapat disimpulkan bahwa rata-rata kompensasi guru SMK Swasta di wilayah 
kepengawasan bagian timur Kabupaten Pemalang termasuk dikategorikan sedang.

Berdasarkan tabel tersebut terdapat beberapa indikator variabel kompensasi yang termasuk kategori sangat tinggi dimana hal tersebut perlu dipertahankan dan ditingkatkan yaitu seperti gaji dan insentif. Sedangkan indikator lainnya rata-rata berada dalam kategori rendah dan sangat rendah sehingga perlu ditingkatkan dan diperbaiki diantaranya adalahtunjangan dan jasa serta kompensasi pelengkap (fringe benefits).

Berdasarkan hasil analisis statistik diperoleh nilai thitung sebesar 4,983 sedangkan nilai ttabel dengan taraf kepercayaan 0,05, menunjukan angka sebesar $1.994(4,983<1.994)$ yang berarti kompesasi (X2) berpengaruh secara signifikan terhadap kepuasan kerja guru SMK Swasta di wilayah kepengawasan bagian timur kab. Pemalang. Sementara itu, nilai koefisien korelasi adalah 0,484. Nilai ini dapat di nterpretasikan bahwa tingkat hubungan kedua variabel penelitian berada pada kategori tinggi. Hal ini berarti bahwa kompensasi (X2) berpengaruh sebesar 48,4\% terhadap kepuasan kerja guru (Y).

Berdasarkan hasil pengujian regresi yang telah diuraikan di atas dapat disimpulkan bahwa hipotesis yang menyatakan adanya pengaruh kompensasi terhadap kepuasan kerja guru SMK Swasta di wilayah kepengawasan bagian timur kab. Pemalang, terbukti. Penelitian lain yang konsisten dengan penelitian ini dilakukan oleh Elviera Sari (2009) Pengaruh Kompensasi dan Iklim Organisasi terhadap Kepuasan Kerja dimana hasil penelitian tersebut adalah Hubungan kompensasi yang diterima karyawan dan iklim organisasi secara bersama-sama menunjukkan hubungan yang sangat kuat dan positif terhadap kepuasankerja, variabel kompensasi yang paling mempengaruhi kepuasan kerja. Kompensasi adalah segala sesuatu yang diterima oleh guru sebagai balas jasa untuk kerja mereka. Kompensasi merupakan salah satu cara yang dapat diberikan oleh sekolah sehingga dapat meningkatkan kepuasan kerja danberimbas pada produktifitas guru terhadap sekolah.

\section{Motivasi Kerja dan Kompensasi terhadap Kepuasan Kerja Guru}

Berdasar hasil pengujian dilakukan dengan tingkat kepercayaan 5\% atau 0,05 diperoleh Fhitung 16,771, dari data tersebut maka Fhitung $>$ Ftabel $(14,110>3.11)$ dengan nilai probabilitas sebesar 0,000 lebih kecil dari 0,05 yang berarti bahwa motivasi kerja dan kompensasi secara bersama sama berpengaruh secara signifikan terhadap kepuasan kerja guru SMK Swasta di wilayah kepengawasan bagian timur kab. Pemalang. Sementara itu jumlah skor untuk kepuasan kerja 7.858 dan rata-rata 94,674 berada di kategori tinggi. Adapun besarnya pengaruh motivasi kerja dan kompensasi berpengaruh terhadap kepuasan kerja gurudapat dilihat dari besarnya $\mathrm{R}$ yaitu sebesar 0,511 maka dikandung maksud besarnya pengaruh adalah $51,1 \%$.

Penelitian ini selaras dengan apa yang telah diungkapkan pada penelitian sebelumnya oleh Susan dan Haryadi (2013) yang menyatakan bahwa motivasi kerja (X1) dan kompensasi (X2) secara bersama-sama memberikan pengaruh yang signifikan terhadap kepuasan kerja (Y) sebesar 58,8\%. Motivasi kerja (X1), kompensasi (X2), dan kepuasan kerja (Y) secara bersama-sama memberikan pengaruh yang signifikan terhadap kinerja Pegawai Negeri Sipil (Z) sebesar 83,8\%. 
Tidak hanya motivasi kerja yang dapat memengaruhi kepuasan kerja guru akan tetapi kompensasi juga sangat memengaruhi kepuasan kerja guru. Motivasi kerja memiliki peran yang cukup besar dalam menumbuhkan kepuasan kerja karyawan, apabila setiap guru di SMK Swasta wilayah kepengawasan bagian timur kab. Pemalang memiliki motivasi kerja yang baik kemudian didukung dengan kompensasi yang layak dari perusahaan baik kompensasi materiil dan non materi maka kepuasan kerja guru akan sangat tinggi.

Motivasi kerja dan kompensasi guru di SMK Swasta wilayah kepengawasan bagian timur kab. Pemalang dikategorikan sedang sementara kepuasan kerja guru di SMK Swasta wilayah kepengawasan bagian timu kab. Pemalang dikategorikan tinggi. Hal ini dimungkinkan adanya pengaruh dari variabel lain yang tidak diteliti yang mengakibatkan kepuasan kerja tinggi. Variabel tersebut dimungkinkan berasal dari Iklim kerja, kepemimpinan kepala sekolah seperti yang telah diungkapkan Sudarto (2012) dan Sari (2009).

\section{KESIMPULAN}

Berdasarkan hasil analisis dan pembahasan yang dilakukan, maka kesimpulan yang dapat dikemukakan dalam penelitian ini adalah sebagai berikut. Motivasi kerja berpengaruh secara signifikan terhadap kepuasan kerja guru SMK Swasta di wilayah kepengawasan bagian timur Kab. Pemalang dan dapat dinterpretasikan bahwa tingkat hubungan kedua variabel penelitian berada pada kategori tinggi antara motivasi kerja terhadap kepuasan kerja guru. Terdapat beberapa indikator variabel motivasi kerja yang termasuk kategori sangat tinggi dan perlu dipertahankan dan ditingkatkan yaitu indikator tanggung jawab. Sedangkan indikator lainnya rata-rata berada dalam kategori tinggi sampai sangat rendah sehingga perlu ditingkatkan dan diperbaiki diantaranya adalah pengembangan, pengakuan/penghargaan, hubungan antar pribadi, serta kebijakan dan administrasi.

Kompensasi berpengaruh secara signifikan terhadap kepuasan kerja guru SMK Swasta di wilayah kepengawasan bagian timur Kab. Pemalang, dan dapat dinterpretasikan bahwa tingkat hubungan kedua variabel penelitian berada pada kategori tinggi antara kompensasi terhadap kepuasan kerja guru. Beberapa indikator variabel kompensasi yang termasuk kategori sangat tinggi dimana hal tersebut perlu dipertahankan dan ditingkatkan yaitu seperti gaji dan insentif. Sedangkan indikator lainnya rata-rata berada dalam kategori sedang dan sangat rendah sehingga perlu ditingkatkan dan diperbaiki diantaranya adalah tunjangan dan jasa serta kompensasi pelengkap (fringe benefits).

Motivasi kerja dan kompensasi secara bersama sama berpengaruh secara signifikan terhadap kepuasan kerja guru SMK Swasta di wilayah kepengawasan bagian timur Kab. Pemalang. Adapun besarnya pengaruh motivasi kerja dan kompensasi berpengaruh terhadap kepuasan kerja guru lebih dari separuh variabel yang dapat mempengaruhi. 


\section{DAFTAR PUSTAKA}

Ardana, I Komang. 2012. Manajemen Sumber Daya Manusia. Yogyakarta: Graha Ilmu.

Hasibuan, Malayu S.P., 2014. Manajemen Sumber Daya Manusia. Jakarta: Bumi Aksara.

Kusuma, I, dan Komang Ardana. 2014. Pengaruh Penempatan dan Kompensasi Terhadap Kepuasan Kerja dan Kinerja Karyawan. E-Jurnal Manajemen Universitas Udayana, 3 (7), 25-37.

Mardiono, Dian. 2014. Pengaruh motivasi dan Disiplin Kerja terhadap Kepuasan Kerja Karyawan. Jurnal Ilmu \& Riset Manajemen, 3 (3).

Rahayuningsih, Sri, Yovitha Yilejantiningsih, dan Ghufron Abdullah. 2015. Pengaruh Kompensasi dan Lingkungan Kerja terhadap Kepuasan Kerja Guru SMP Negeri di Sub Rayon 02 Pecangaan Kabupaten Jepara. Jurnal Manajemen Pendidikan, No. 14, 33-45.

Robbins, Stephen P. T A Judge. 2010. Organizational Behavior. Jakarta: Salemba Empat.

Saleem, Rizwan, Azeem Mahmood, dan Asif Mahmood. 2010. Effect of Work Motivation on Job Satisfaction in Mobile Telecommunication Service Organizations of Pakistan. International Journal of Business and Management, 5 (11). https://doi.org/10.5539/ijbm.v5n11p213.

Situmorang, Susan Novita Rotua, dan Haryadi Sarjono. 2013. Pengaruh Motivasi Kerja dan Kompensasi terhadap Kepuasan Kerja serta Dampaknya pada Kinerja Pegawai Negeri Sipil Kantor Kecamatan Kebon Jeruk, Jakarta Barat. Jurnal Ekonomi, 4 (1).

Sohail, A. et al. 2014. Effect of Work Motivation and Organizational Commitment on Job Satisfaction: (A Case of Education Industry in Pakistan). Global Journal of Management And Business Research, 14(6), 41-46. https://journalofbusiness.org/index.php/GJMBR/article/view/1320.

Sudharto. 2011. Pengaruh Kepemimpinan Kepala Sekolah dan Kompensasi terhadap Kepuasan Kerja Guru SMPN Kota Semarang". Jurnal Cakrawala Pendidikan, $X X X, 3$.

Sutrisno, Edy, 2012. Manajemen Sumber Daya Manusia. Jakarta: Prenada Media Group. 